\title{
THE CORRELATION BETWEEN STUDENTS' SIMPLE PAST TENSE MASTERY AND THEIR ABILITY IN TRANSLATING NARRATIVE TEXT PROBLEMS FACED BY STUDENTS IN APPLYING GRAMMAR ON SPEAKING SKILL AT ABA UMI STUDENTS 2017/2018
}

\author{
Ratnawati ${ }^{1}$, Sulastri ${ }^{2}$ \\ Universitas Muslim Indonesia (UMI) Makassar,Indonesia ${ }^{12}$ \\ ratnawati.ratnawati@umi.ac.id ${ }^{1}$ \\ sulastri.sulastri@umi.ac.id ${ }^{2}$
}

\begin{abstract}
This research was about the problems faced by students in applying grammar on speaking skill at the second semester students at ABA UMI. This research was carried to find out and analyze the types of problems encountered by students. In doing the research, the researchers used qualitative approach which involved descriptive method in it. Then, the data were collected through the questionnaire. The researchers took 23 students as the sample then gave the students test that consisted of 30 items: 25 multiple choice and 5 essays questions. There were four types of errors which were usually made by students of second semester students. They were omission, addition, misformation, and misordering. From the questionnaire finding, the results showed that based on the rate of the grammar problems faced by students percentage total error of omission is 14 on the percentage $0,60 \%$, total error of addition is 18 on the percentage $0,78 \%$, total error of misformation is 21 on the percentage $0,91 \%$, and total error of misoredering 10 on the percentage $0,43 \%$. It is followed by the problems speaking skill with mean percentage, of grammar is $64 \%$, vocabulary $25 \%$, and Pronunciation 11\%.In conclusion, problems in the application of grammar on speaking skill is higher, it concluded that the grammar problems still become barrier that affect students speaking skill.
\end{abstract}

Keywords: Problems of Grammar, Speaking skill, ABA Students.

\section{Introduction}

Grammar is one of the most difficult aspects of a foreign language to master. It is defined as the rules that govern how a language sentences are formed (Elturki, in Thornbury, 2000:1). English grammar has been traditionally viewed as a system of syntax that decides the order and patterns in which words are arranged in sentences (Elturki, in Close, 1982:13). It is argued that mastering grammar is a complex process that requires "making a series of decisions about when and why to use one form rather than the other (Elturki, in Murcia, 2002:121). 
According to Ningsih, 2017:46, in Hidayah (2013:2), grammar is the system of rules governing the conventional arrangement and relationship of words in a sentence. It means that grammar is as the guidance of speaking for students to make the correct sentences and to convey the message property in particular spoken form. To make English sentence either written or spoken, tense has very important role because tense expresses an action happened based on time. (Ningsih, 2017:46, in Jabbari, 2013:245) explains that tense refers to the grammatical changes made to the form of a verb, as opposed to time, which refers to the semantic functions such changes signal.

\section{Tenses In English}

Learning English is related to tenses. Tenses refer to time. However, tenses are different with time. According to Sukmawati, 2016:21, in Decklercket a1, (2006) 'time is an extralinguistic category'. It stands independently. Then, they also state that tenses are a kind of linguistic concept. It denotes the form taken by the verb to locate the situation referred to in time. There are several names for tenses in English but Simple Present and Present Perfect are the main focus of this research.

\section{a. Simple Present Tense}

Simple Present Tense is one of the several tenses which has a function to tell a fact or a habitual activity. (Sukmawati, 2016:21, in Azar, 1999) says, 'the simple present says that something was true in the past, is true in the present, and will be true in the future'. It also expresses general statements of fact and timeless truths and also explains that simple present can be used to express habitual or everyday activities.

Table 1. The Examples and Functions of Simple Present Tense (Sukmawati, 2016:22, in Azhar: 1999)

\begin{tabular}{|l|l|}
\hline \multicolumn{1}{|c|}{ Examples } & \multicolumn{1}{|c|}{ Function } \\
\hline $\begin{array}{l}\text { a. Water consists of hydrogen and oxygen } \\
\text { b. The average person breathes 21,600 times a day. } \\
\text { c. The world is round. }\end{array}$ & $\begin{array}{l}\text { To express general statements } \\
\text { of fact and timeless truths. }\end{array}$ \\
\hline $\begin{array}{l}\text { d. I study for two hours every night. } \\
\text { e. I get up at seven every morning. } \\
\text { f. He always eats a sandwich for lunch }\end{array}$ & $\begin{array}{l}\text { To express habitual or everyday } \\
\text { activities. }\end{array}$ \\
\hline
\end{tabular}


Besides, the use of Simple Present to express habitual or everyday activities can be seen in the example (d), (e) and (f). Those examples show that someone usually studies for two hours, gets up at seven, and eats lunch with a sandwich, the subject does the activities every day as a habit.

The form of sentences can be positive, negative, or interrogative sentences. Simple Present Tense also has its pattern of positive, negative, and question form of sentences. The form of the main verb may be different depending on the subject chosen. The use of the subject in every sentence determines the form of the main verb.

The general pattern of Simple Present Tense is $S+V 1$ the $V 1$ will be added $-S$ or es if the subject is the third person. The table shows that the examples of the third person subject are $\mathrm{He}$, She and it. Therefore, the verb walk is added $s$ becoming walks because the subject is the third person. Then, if it comes to an interrogative sentence, the auxiliary do isused for the first or second person of the subjects and if the subject is third person, the auxiliary which is used is does. Both are the rules in present form.

Another pattern of Simple Present Tense is $S+$ to be. Like what the researchers have explained above, Simple Present Tense in using to be has similar rules as Simple Present Tense in using a verb. Generally students are not able to distinguish between Present Tense and Present Continuous. For example: Ramesh is going to the college daily. This sentence is considered to be correct by many, but grammatically the sentence is wrong. Therefore it needs correction: Ramesh goes to college daily

\section{a. Present Perfect}

Sukmawati, 2016:25, in Azar (1999), there are three functions of Present Perfect. It expresses an idea of something which happened or even never happened before now, and does not have specified time in the past, repetition of an activity before now, and to express a situation that began in the past and still continues to the present.

\section{Table 2. Examples and Functions of Present Perfect}

\begin{tabular}{|c|c|}
\hline Examples & Functions \\
\hline $\begin{array}{l}\text { a. They have moved into a new } \\
\text { apartment. } \\
\text { b. I have never seen snow. }\end{array}$ & $\begin{array}{l}\text { To express an idea that something } \\
\text { happened or even never happened before } \\
\text { now. }\end{array}$ \\
\hline
\end{tabular}




\begin{tabular}{|c|c|}
\hline c. I have already seen that movie. & \\
\hline $\begin{array}{l}\text { d. We have had four tests so far this } \\
\text { semester. } \\
\text { e. I have met many people since I came } \\
\text { here in June. } \\
\text { f. I have flown on an airplane many } \\
\text { times. }\end{array}$ & $\begin{array}{l}\text { To express repetition of an activity } \\
\text { before now. }\end{array}$ \\
\hline $\begin{array}{l}\text { g. I have been here since seven o'clock. } \\
\text { h. We have been here for two weeks. } \\
\text { i. I have had this same pair of shoes for } \\
\text { three years. }\end{array}$ & $\begin{array}{l}\text { To express a situation that began in } \\
\text { the past and continuous to the } \\
\text { present. }\end{array}$ \\
\hline
\end{tabular}

Sukmawati, 2016:26, in O'Dawyer (2006), the activity of Present Perfect is started in the past. He also explains that although the activity is started in the past, it still has some relationship to the present time. The verb formation of Present Perfect is have/has + past participle (V3).

Generally, Present Perfect has the same rules as Simple Present Tense. The word have will change into has if the subject is the third person. While if the subject is the first or second person. The verb formation uses have. Then, if the past participle uses to be (is. am, are), the formation would be $\mathrm{S}+$ Have/Has + been $+(\mathrm{O} / \mathrm{C})$.

According to Parrot (2010:162), he says as general, learners have far more difficulty in using present correctly than in understanding them. Even if they don't know or are unclear about the differences in meaning between different tense, in most case there is plenty of information in the context to help them understand whether, for example, an action is temporary or not. He make some typical difficulties for learner when they study the present Perfect, they are: form and meaning, the use of how long with for and since, and over use of present perfect form (Parrot, 2010:163). Some students still have difficulty in understanding the form of present Perfect. He also gives the examples of error made by students in form of present perfect especially in putting have/has for subject:

"I has lost my chance to study abroad", or "She have finished her homework"

Correct :

"I have lost my chance to study abroad", or "She has finished her homework". 
Basically, the rules of using Simple Present and Present Perfect are just the same. The differences are in the functions and in the pattern or the verb formation.

\section{Types of Errors}

Surface strategy taxonomy from Dulay et al. (1982) is used to analyze the errors of this study. Surface strategy taxonomy analyzes the change of the surface structures of the sentences. Based on the surface taxonomy strategy, errors are classified omission, addition, misformation, and misordering.

\section{a. Omission}

Omission errors is a type of error which occurs if there are one or more items that do not appear in a well-formed of utterances. Any morpheme or word which does not appear like it should be can be categorized as omission but grammatical morphemes are more frequent to be omitted by learners rather than the content words, For example:

\section{"Mary an English teacher"}

The sentence is potential to categorize as omission. Although the sentence is still understandable, it omits grammatical morpheme "is" for present tense or "was" on past form. The sentence should be like this Mary is an English teacher. Grammatical morpheme like $i s$ is word which has a minor role in the case of the meaning of a sentence. Besides, in case of grammar, grammatical morphemes like noun and verb inflections (the -s in dogs, the -s in Sister's, the -ed in watched, the -ing in looking, etc); articles (a, the, etc); verb auxiliaries (is, can, will, etc); and preposition (in, at, on, etc) are really important to be used in a sentence. Therefore, if there is an item in a sentence which is absent and making an unwell-formed utterance, it can be stated as omission.

\section{b. Addition}

In contrast with omission, Dulayet a1. (1982) explain that addition errors are defined by 'the presence of an item which must not appear in a well-formed utterance'. They also state that there are three types of addition errors. Those are double markings, regularizations, and simple additions.

\section{1) Double Markings}

The tense formation in English rule shows that the tense marker is on the first verb. If there is an affirmative declarative sentence, the tense marker is the main verb. The main 
verb is the only verb of the sentence because there is no other verb in the sentence. While, it is different if a sentence needs an auxiliary. The main verb is not the tense marker. The tense marker is the auxiliary. For example:

"She doesn't buy the book or They didn't go to the party".

The auxiliaries does and did are the tense marker of the sentence. However, placing the marker on both, the verb and auxiliary, may occur toward learners, for example:

(a) He doesn't goes to school. or

(b) She didn't went there.

Both the auxiliary and the main verb are marked for the same tense. This type of addition error is called double marking.

2) Regularizations

Regularization errors are 'those in which a marker that is typically added to a linguistic item is erroneously added to exceptional items of the given class that do not take a marker'. This error typically happens among learners in the use of regular and irregular forms, for example:

(a) Budi buyed a book yesterday. Or

(b) There are five sheeps in the field.

The verb buy does not become buyed, but bought; the noun sheep does not become sheeps in the plural, the plural form of sheep is also sheep. This type of addition error has been called as regularization.

\section{3) Simple Additions}

There is no specific feature which can be categorized as simple additions. Simple addition errors are addition errors which are not categorized as double marking and regularization. Dulayet a1. (1982) states 'if an addition error is not double marking nor a regularization, it is called a simple addition, for example:

\section{"This is a books".}

The word books should be book without addition -s because the sentence states that the book is singular not plural. This kind of addition is categorized as simple addition. 


\section{c. Misformation}

Dulayet a1. (1982) explain that misformation errors are kind of addition errors which do not have the correct form of the morpheme or structure. There are three types of misformation errors. Those are regularization errors, archi-forms, and alternating forms.

\section{1) Regularization errors}

Dulay et al. (1982) say that 'misfonnation category are those in which a regular marker is used in place an irregular one'. For example:

"the word patted for put or gooses for geese".

It is the same case as regularization in addition errors.

\section{2) Archi-form}

Based on Dulayet a1 (1982), they say archi-form is 'the selection of one member of a class of forms to represent others in the class'. The example is an error of using English demonstrative adjectives this, that, these, those. Like for example the phrase that dogs which should be those dogs.

3) Alternating form

Dulay et al. (1982) state that 'the use of archi-forms often gives way to the apparently fairly free alternation of various members of a class with each other'. So, learners may do alternation in the sentence structure, for example:

"I seen her yesterday instead of I saw her yesterday or I have gave you instead of I have given you".

\section{d. Misordering}

Misordering errors are characterized by 'the incorrect placement of a morpheme or group of morphemes in an utterance'. The morphemes do not take place in where it should be, for example:

"She is a person lazy".

The word person is misordered. The sentence should be She is a lazyperson. Another example can be seen in this question form

"What John is doing?" 
The correct one is What is John doing? Learners may commit this kind of error because they are usual to hear the phrase -is doing so when they implement it in question form they forget to change into the right order of question form.

\section{Definition of Speaking}

There are a lot of definitions of the word "speaking" that have been suggested by the researchers in language learning. In Webster New World Dictionary, speaking is to say words orally, to communicate as by talking, to make a request and to make a speech. According to Leong and Ahmad, 2017:35, in Chaney (1998), speaking is the process of making and sharing meaning by using verbal and non verbal symbols in different contexts. Defined speaking as an interactive process of making meaning that includes producing, receiving and processing information.

Leong and Ahmad, 2017:35, in Bygate ( 1987) defined speaking as the production of auditory signals to produce different verbal responses in listeners It is regarded as combining sounds systematically to form meaningful sentences. (Leong and Ahmad, 2017:35, in Eekard and Kearny, 1981), defined speaking as a two-way process including a true communication of opinions, information, or emotions. This top down view regards the spoken texts as the collaboration between two or more persons in the shared time and the shared context.

\section{Characteristics on Speaking Skill}

According to Leong and Ahmad, 2017:36, in Mazouzi (2013), learners' activities should be designed based on equivalence between fluency and accuracy achievement. Both fluency and accuracy are important elements of communicative approach. Classroom practice can help learners develop their communicative competence. So they should know how the language system works appropriately.

The first characteristic of speaking performance is fluency and it is the main aim of teachers in teaching speaking skill. According to Leong and Ahmad, 2017:36, in Hughes (2002), fluency is the learners' ability to speak in understandable way in order not to break down communication because listeners may lose their interest.

The second characteristic of speaking performance is accuracy. Learners should be fluent in learning a foreign language. Therefore teachers should emphasize accuracy in 
their teaching process. Learners should pay enough attention to the exactness and the completeness of language form when speaking such as focusing on grammatical structures, vocabulary, and pronunciation.

According to Leong and Ahmad, 2017:36, in Thornbury (2005), learners' correct use of grammatical structures requires the length and complexity of the utterances and the wellstructured clauses. To gain accuracy in terms of vocabulary means to select suitable words in the suitable contexts. Learners sometimes apply similar words or expressions in various contexts which do not mean similar things. So learners should be able to use words and expressions correctly.

Declared that pronunciation is the lowest level of knowledge learners typically pays attention to it. In order to speak English language accurately, learners should master phonological rules and they should be aware of the various sounds and their pronunciation. Learners should also know the stress, intonation, and pitch. All of these elements help learners speak the English language easily and effectively.

\section{Speaking Problems}

There are some problems for speaking skill that teachers can come across in helping students to speak in the classroom. These are inhibition, lack of topical knowledge, low participation, and mother tongue use (Leong and Ahmad, 2017:36, in Tuan \& Mai, 2015).

The first problem is inhibition that encounters students in class. When they want to say something in the classroom they are sometimes inhibited, they are worried about making mistakes and fearful of criticism, and they are ashamed of the other students' attention towards themselves. The second problem is that learners complain that they cannot remember anything to say and they do not have any motivation to express themselves. This is supported by Rivers (I968) who thinks that learners often have nothing to say probably because their teachers had selected a topic that is not appropriate for them or they do have enough information about it. Also supports the above idea and stated that it is very difficult for learners to answer when their teachers ask them to tell things in a foreign language because they have little opinions about what to say, which vocabulary to apply, or how to use grammar accurately. The third problem in the speaking class is that the participation is very low. In a class with a large number of students each student will have 
very little time for talking because just one student talks at a time and the other student try to hear him/her. In the speaking class, some learners dominate the whole class while others talk very little or never speak.

The last problem related to the speaking ability is that when some learners share the same mother tongue, they try to use it in the speaking class because it is very easy for them. According to Leong and Ahmad, 2017:36, in Harmer (1991), there are some reasons why learners use mother tongue in their speaking classes.

a. The first reason is that when teachers ask their learners to talk about a topic that they do not have enough knowledge, they will try to use their language.

b. The second reason is that the application of mother tongue is very natural for learners to use. If teachers do not urge their learners to talk in English. Learners will automatically use their first language to explain something to their classmates.

\section{Problems in Applying Grammar on Speaking Skill}

Speaking skill in second or foreign language is a challenge for the learners, because to speak a foreign language such as English requires more than knowing grammar but also the use of English in a real context. (Fitriani, et al, 2014:4, in Hayriye, 2006) state that speaking is to select appropriate words and sentences according to the proper social setting, audience, situation, and subject matter. Being a fluent speaker requires many knowledge towards the language learnt itself and its usage in the real communication.

According to Fitriani, et al, 2014:4, in Doris and Jessica (2007), language problems actually serve as one of the important reasons behind poor academic performance. These problems may become the obstacles for the students to enhance and improve their speaking ability. The reasons why the students are having problems in their speaking are they are poor in grammar, vocabulary, and pronunciation. Those problems are belong to linguistics problems.

Linguistics problems are those problems which make students speaking ability become poor. There are some linguistics problems that affect someone in speaking, such as poor in grammar, lack of vocabulary and pronunciation. (Fitriani, et al, 2014:4, in Richards, 2008) claim there are some typical learners' problems in speaking, they are lack of 
vocabulary needed to talk, poor in pronunciation, and poor in grammar. Grammar is a study in which sentences are structured and formatted, so that it may be considered a bit boring to study correct grammar since it really is worth the time and effort. If learners do not know the rules of grammar, they will never be able to communicate using English effectively. According to Fitriani, et al, 2014:5, in Celce-Murcia (2001), grammar become difficult because learners do not learn structures one in a time. Even the learners appear to have mastered a particular structures; it is not uncommon to find backsliding occurring with the introduction of new form to the learners' interlanguage. For example, the learner who has mastered the third singular person marker on the present tense verb is likely to overgeneralize the rule and apply it to newly emerging modal verb, thus producing problems such as "she cans speak English". These problems may appear when the students speak since they have not mastered the English grammar.

\section{Methodology}

The researchers used the qualitative approach which involved the descriptive method in it. There was one variable or a single case study that was students focus on Simple Present Tense and Present Perfect. This Research conducted in Foreign Language Academy Muslim University of Indonesia Makassar Academic Year of 2017/2018 in April 2018. The research used random sampling technique. The researchers took 23 Students from five classes of the second semester at ABA UMI Students 2017/2018.

In this research, the researchers used test. The test consisted of 25 multiple choice and 5 questions. Furthermore, the writer collected the data based on the test given. All the documents completely used as the data of the research. After obtaining the data, the writer started to identify the data as the steps previously stated. The writer used two main steps. The first step was the writer identified the data and then analyzed it.

\section{Findings}

Based on data obtained by researchers, it can be found that there were several students who have problems in using Simple Present Tenses and Present Perfects in the application of grammar on speaking skill. In this research after identified and analysis data obtained, the results by research there are two major dominant the students' problems on grammar and Speaking skill. 


\section{Grammar}

Based on grammar of Speaking skill consist of both the writer just focus of simple present and present perfect sentences made by the students problems. The writer classified those sentences into each Type of Error namely errors of Omission, errors of Addition, errors of Misformation, and errors of Misordering. The errors found were analyzed using the surface strategy taxonomy proposed by Dulayet al. (1982)

The researchers have calculated the total of problems percentage of each type and here are results of the classification could be seen in the table follows.

Table 1 Total Types of Errors the second semester ABA UMI students the Problems on Simple Present and Present Perfect.

\begin{tabular}{|ccc|}
\hline \multicolumn{3}{c|}{ Total Types of Errors Simple Present Tenses and Present Perfect } \\
\hline Types & Total Students & Percentage \\
Omission & 14 & $0.60 \%$ \\
Misformation & 21 & $0.91 \%$ \\
Addition & 18 & $0.78 \%$ \\
Misordering & 10 & $0.43 \%$ \\
Total & 23 & $100 \%$ \\
\hline
\end{tabular}

\section{Speaking Skill}

To analyze the students' problems on speaking skill, the analysis focused on the three components of problems Speaking skill. They were lack of vocabulary needed to talk, poor in pronunciation, and poor in grammar.

To know the students reasons in facing the problems of Speaking skill, the data were gained on test from five sources question given. The results there were some reasons why the students faced the problems in the application of grammar on Speaking skill until the results from five questions given, the writer just focus in this question about "what are the problems in the application of grammar on Speaking skill". So from the calculation result in this the description of the students answer, here are results of the classification could be seen in the figure follows. 
Figure 1. The Percentage Description Answer of ABA UMI Students

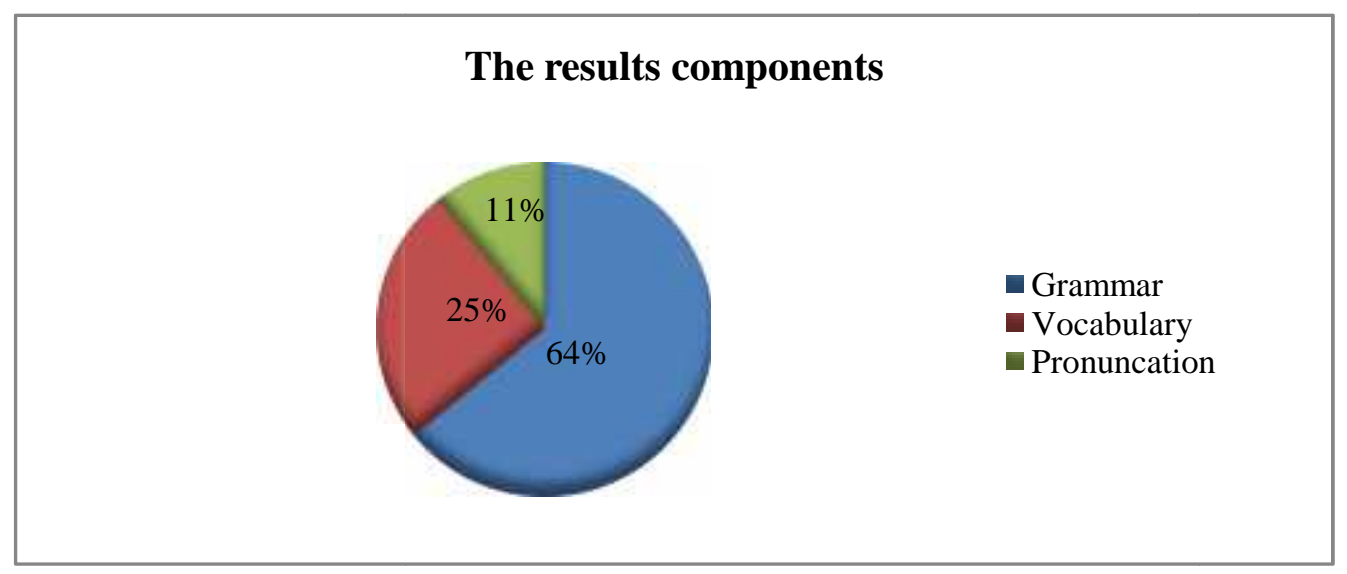

\section{Discussion}

It can be seen from the results of this research, data from the test were collected to investigate the grammar problems. The data from the test also investigated the aspect of the problems speaking skill; those are grammar problem, vocabulary problem, pronunciation problem.

Based on the findings, the analysis from the data obtained by using test about grammar problems and just focus in Simple Present Tenses and Present Perfect. After identifying and classifying the sentences, the writer, then, analyzed and classified the problems made by 23 students based on Dulay's theory.

Besides, the research discussed some problems which were made by the students in Simple Present and Present Perfect. The problems sentences discussed below were based on the data findings which were put in the appendix. The problems could be seen as follows.

\section{Error of Omission}

As seen in the table presented above, the most frequent problems made by the students were the error of omission. The researchers found out that there were 14 students error in omission error with the percentage of $0,60 \%$. These following sentences are results of errors omission made by the students.

Example: "Our Math teacher doesn't checks the attendance list every day". (Error) 


\section{7nspiring: English Education Dournal}

Volume I No 2 September2018

It should be "Our Math teacher doesn't check the attendance list every day". (Cause of error: the students did not understand the contraction of does not).

\section{Error of Misformation}

The second types of errors which were mostly made by the students were the error of misformation there were 21 students error in misformaion with the percentage of $0,91 \%$. A good sentence should have correct morpheme or structure. If the sentence does not have correct form of morpheme or structure it can be categorized as misformation error. Here some sentences of misformation errors students made based on the data.

Example: "ayyashfly to dubai every month" (error)

It should be "ayyash flies to dubai every month". (cause of error: it was influenced by the lack of understanding in forming verb).

\section{Error of addition}

Addition error was the next type of error which appeared in the data finding, addition error can be said as the opposite of omission error type. Addition, error is characterized by the presence of an item which is unnecessary or mostly not appears in well-formed sentences. It means that the speakers or the writers add some words that should not appear in the sentences they made. There were 18 students error in addition error with the percentage of $0,78 \%$.

Example: "The children have been eaten their breakfast".

It should be "The children have just eaten their breakfast". (Cause of error: the students did not understand on structure).

\section{Error of misordering}

The next type of error is misorderingerror, misordring was the fewest type of error which occurrence in the data finding. This kind of errors is characterized by the incorrect placement of a morpheme or group of morphemes in an utterance. There were 10 students error in type error of misordering with the perecentage of $0,43 \%$ from all types of errors.

\section{Example: "Do your Uncle come here every year?"}

It should be "Does your Uncle come here every year?" (Cause of error: the students were not able to identify the subject in sentence and they did not know the pattern of negative sentences). 
After that, besides from discussion about the grammar problems focus in Present Tenses and Present Perfect, the writer also discussed about the problem Speaking skill as for based on the data finding about the problems speaking skill. Furthermore, from the data displayed in the figure which is shown the sum percentage, it also answers concerning the problem in the application of grammar on speaking skill. Which belongs to 23 students as the samples of the study, based on the three problems component from the students answer, the proportions are as follows?

a. The percentage of grammar is $64 \%$ which has the higher, it is clear that the grammar problems still become barrier that affect students Speaking skill.

b. While the second problem which may affect students speaking skill is the Vocabulary problems with total percentage $25 \%$, this emphasized that vocabulary plays an important role to students speaking skill.

c. Moreover the third problem of the students speaking skill problem is the pronunciation (linguistics problem) with total percentage $11 \%$. It can be concluded that the most dominant problem faced by the second semester students ABA is Grammar.

\section{Conclusion}

In order to find out what is the most dominant problem in students problems in the application of grammar on Speaking skill, the researcher used a test type which consists of 25 Multiple Choice regarding to students grammar problems and focus on Simple Present Tenses and Present Perfect.. The testswere divided into 2 main aspects, namely grammar problems and speaking skill problems. The grammar problems are the problems related based on the finding of the analysis, it was found that the students made lots of problems in using Simple Present and Present Perfect, the types of error made by the students of ABA UMI the second semester were namely: Omission, Addition, Misformation and Misordering.

Furthermore, based on the result of the research and also used a test type which consists of 5 questions regarding to students Speaking Problems in the application of 
grammar. The Problems Speaking Skill are the problems related from the students answer based on the finding to students are they were lack of vocabulary needed to talk, poor in pronunciation, and poor in grammar, the most dominant problem faced by the students was determined by the components.

\section{References}

Ary, D. 2010.Introduction to Research in Education.Canada: Nelson Education, Ltd.

Arikunto, S. 2002. ProsedurPenelitianSuatu Media PendekatanPraktek.Jakarta: RinekaCipta.

Elturki, Eman. 2011. An Investigation of grammar problem Facing English Language Learners. Research, at Washington State University, Literacy and Technology Program, an ESL teacher at the Intensive America Languange Center of Washington State University. E-mail: eman.elturk@email.wsu.edu. viewed on: $10^{\text {th }}$ Maret 2018.

Fitriani, D., Wati, R., \&Wardah, 2014.A Study on Student's English Speaking Problems in Speaking Performance, Article. Pontianak: English Education Study Program, Language and Arts Education Departmaent, Teacher Training and Education Faculty of Tanjungpura University. viewed on: $20^{\text {th }}$ Maret 2018.

Leong, L., \& Ahmad, S., 2017. An Analysis of Factors Influencing Learners' English Speaking Skill.International Journal of Research in English Education.UniversitiSains Malaysia \& University of Guilan, Rasht, Iran. available at: www.ijreeonline.com.viewed on: $12^{\text {th }}$ Maret 2018.

Ningsi, wahyu. 2017. Student's error in using simple present tense at the second grade of SMK Negri 3 Medan.International Journal of Language Learning and Applied Lingguistics World (IJLLALW) .Universitas of North Sumatera, Prodi LinguistikUniversitas Sumatera Utara.available at: www.ijllalw.orgviewed on: $12^{\text {th }}$ Maret 2018.

Sukmawati, Agnes Listi. 2016. An Error Analysis of Simple Present and Present Perfects of Students' Writing in Critical Reading and Writing Course. Thesis. Yogyakarta: Sanata Dharma University. Faculty of Teachers Training and Education.viewed on: $12^{\text {th }}$ Maret 2018.

Swan, Michael. 2005. Practical English Usage: $3^{\text {rd }}$ Edition. Oxford University Press 